\title{
HUBUNGAN INFORMASI DALAM KEGIATAN PROMOSI ALL ABOUT WEDDING DENGAN SIKAP PESERTA TERHADAP VENDOR WEDDING LINTAS
}

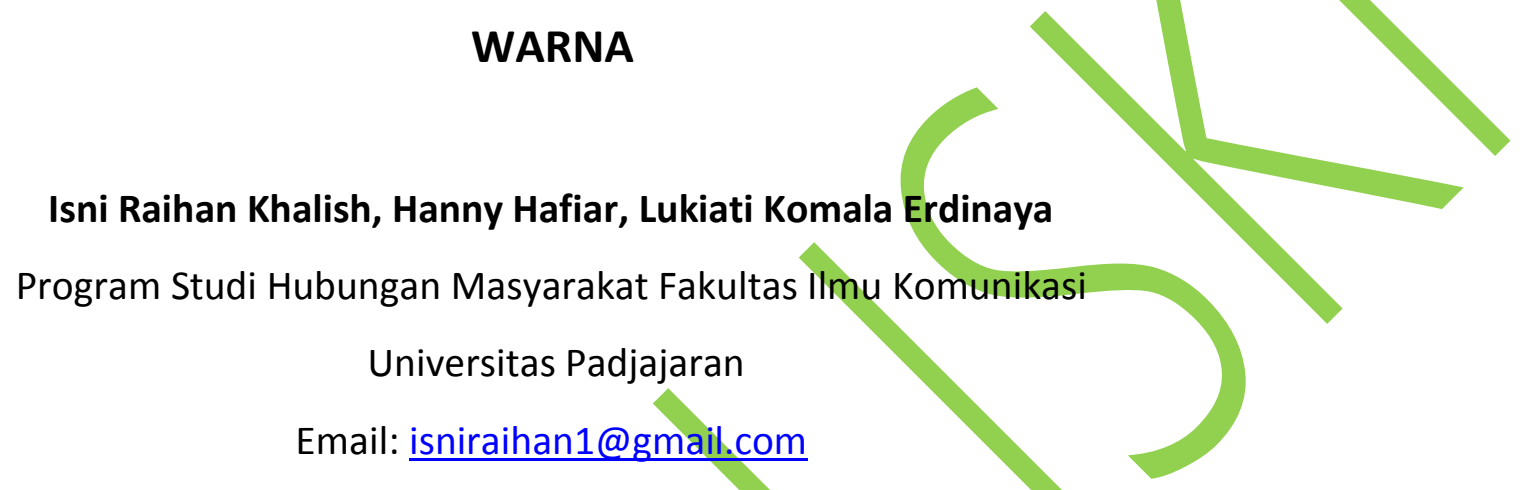

ABSTRAK

Tulisan ini bertujuan untuk mengetahui hubungan antara valensi informasi dan bobot informasi pada kegiatan promosi All About Wedding dengan sikap peserta terhadap vendor wedding Lintas Warna. Penelitian ini menggunakan teori komunikasi yaitu Integrasi Informasi yang dikemukakan oleh Martin Fishbein. Metode penelitian yang digunakan dalam penelitian ini adalah metode penelitian kuantitatif dengan teknik analisis korelasional. Teknik pengumpulan data melalui angket, wawancara, observasi dan studi kepustakaan. Populasi penelitian ini adalah seluruh peserta pada kegiatan promosi All About Wedding pada tanggal 19 Desember 2015. Teknik penarikan sampel yang diterapkan dalam penelitian ini yaitu teknik Sample Random Sampling dengan jumlah sampel 72 orang. Uji validitas menggunakan rumus Rank Spearman dan Uji Realibilitas menggunakan rumus Alpha Cronboach. Teknik analisis data deskriptif dalam statistik inferensial melalui uji hipotesis Rank Spearman. Hasil penelitian ini menunjukkan bahwa terdapat hubungan antara informasi pada kegiatan promosi All About Wedding dengan sikap peserta terhadap vendor wedding Lintas Warna. Kekuatan hubungan berada pada kategori cukup berarti antara kedua variable tersebut. Namun tidak cukup besar dalam membentuk sikap peserta untuk menggunakan vendor wedding Lintas Warna.Kesimpulan dari penelitian ini yaitu Valensi informasi dan Bobot informasi memiliki hubungan yang cukup berarti dengan sikap peserta terhadap vendor wedding Lintas Warna. Walaupun masih terdapat informasi yang dipandang kurang meyakinkan, tidak jelas, dan tidak detail setelah peserta mengakumulasikan informasi pada kegiatan promosi. Saran dari penelitian ini yaitu sebaiknya Lintas Warna event organizer melakukan pemeriksaan ulang terhadap panduan informasi agar informasi tersampaikan secara detail dan sesuai dengan yang disampaikan oleh penjaga stand dan pada brosur Lintas Warna.

Kata Kunci : Informasi, Kegiatan Promosi, Sikap, Valensi Informasi, Bobot Informasi 


\begin{abstract}
This paper aims to determine the correlation between valence's information belief and weight of information credibility on the promotion activities of All About Wedding with the attitude of the participants towards Lintas Warna vendor wedding. This study used communication theory called Information Integration from Martin Fishbein. The method in thisi research is the quantitative method with analysis technique correlational. Thecniques of collecting data by questionnaires, interviews, observation and literature studies. Population of this research are all the participants on the activities of promostion All About Wedding on 19 December 2015 disproportional Sample Random Sampling was used for The samling technique with a sample of 72 people. The Validity test used was Rank Spearman and The Reliability Test used Alpha Cronboach Formula. Data Analysis Techniques of descriptive and inferential statistics through hypothesis test Spearman Rank. The results of this research showed that has a correlations between information with the attitude of the participants towards Lintas Warna vendor wedding. The strength correlations is significant correlationas between both of two variables. But isn't big enough in shaping the participants to use a vendor wedding Lintas Warna.Conclusion from this research which is There is strong correlations between valence's information with attitude of the participants. And meaningful correlations between weight of information with participants's attitude. Although there are still information which is considered less convincing, it is unclear and no details after the participants accumulate information on promotion activites. Suggestions from this research that should Lintas Warna event organizer do a re-examination of the information guide for the information conveyed in detail and in accordance with that delivered by the guard booth and at Lintas Warna brochure.
\end{abstract}

Keywords : Information, Promotion Activities, Attitudes, valence's information, weight of information 


\section{PENDAHULUAN}

Pada era globalisasi saat ini perusahaan jasa yang menyediakan jasa dalam membantu calon pengantin dan keluarga dalam perencanaan dan pelaksanaan resepsi pernikahan sudah banyak ditemui. Saat ini, para calon pengantin yang akan melaksanakan sebuah resepsi pernikahan tidak akan sulit untuk menentukan vendor wedding yang akan digunakan dalam resepsi pernikahannya. Dengan kemajuan teknologi calon pengantin bisa mencari dan mendapatkan informasi tentang berbagai hal yang bersangkutan dengan pelaksanaan sebuah resepsi pernikahan.

Calon pengantin dan keluarga dapat mencari informasi melalui website atau akun media sosial dari berbagai vendor wedding khususnya di Kota Bandung yang kini sudah banyak vendor-vendor wedding terbentuk. Ditunjang pula dengan berbagai pameran pernikahan di kota Bandung yang secara rutin diselenggarakan oleh beberapa event organizer baik pameran pernikahan tradisional maupun internasional. Maka dari itu, saat ini para calon pengantin beserta keluarganya bisa dengan mudah mencari informasi tentang jasa vendor wedding untuk pelaksanaan sebuah resepsi pernikahan. Informasi tersebut dapat dicari melalui website, media sosial seperti facebook, instagram, youtube atau dapat mendatangi langsung pameran pernikahan.

Lintas Warna event organizer adalah sebuah event organizer di kota Bandung yang berdiri sejak tahun 2008 dan sudah banyak mengorganisir acara-acara di kota Bandung. Acara yang diselenggarakan berkaitan dengan sebuah penyelenggaraan pernikahan seperti pameran pernikahan tradisional maupun internasional secara rutin tiap tahunnya. Pada tahun 2009 Lintas Warna event organizer membentuk sebuah management wedding yang didalamnya terdapat lima jenis vendor wedding yang tergabung, antara lain : satu vendor cathering bernama "Samudera Cathering, satu vendor Foto dan video bernama "the motion", satu vendor make up dan kebaya "D’Rasty Wedding" dan satu vendor music entertainment bernama "Samiimusic", satu vendor kartu undangan dan souvenir "D\&Co design". Management Wedding Lintas Warna mulai dipromosikan pada tahun 2013 melalui 
beberapa kegiatan promosi dalam sebuah pameran pernikahan tradisional di kota Bandung.

Kegiatan promosi tersebut dilaksanakan di hari kedua pameran pernikahan yang diselenggarakan pada tanggal 18-20 Desember 2015. Menurut informasi dari owner Lintas Warna kegiatan ini adalah sebuah kegiatan promosi yang sudah diselenggarakan sebanyak tiga kali sejak tahun 2013. Pada penelitian ini kegiatan promosi yan dijadikan sebagai objek penelitian yaitu kegiatan promosi yang diselenggarakan pada tanggal 19 Desember 2015.

Kegiatan ini diberi nama "All About Wedding" dan diselenggarakan pada hari kedua pameran bertempat di Pusat Dakwah Islam Bandung. Kegiatan Promosi All About Wedding ini diselenggarakan di sebuah big stage pameran pernikahan bertempat di Pusat Dakwah Islam (Pusdai) dan dihadiri oleh calon pengantin yang datang sebagai peserta. Dalam kegiatan ini juga mendata peserta yang hadir dalam kegiatan ini dengan menyediakan buku tamu. Peserta All About Wedding pada tanggal 19 Desember 2015 ini adalah calon pasangan pengantin yang sebelumnya sudah mencari dan mendapatkan informasi mengenai management wedding Lintas Warna melalui website Lintas Warna event organizer dan akun facebook Lintas Warna. Informasi dari humas Lintas Warna mayoritas peserta-peserta ini sudah melakukan pencarian informasi sebelumnya melalui internet untuk mencari informasi pelaksanaan kegiatan promosi oleh Lintas Warna event organizer. Mereka sudah mengetahui tentang pelaksanaan pameran pernikahan Lintas Warna dan kegiatan promosi All About Wedding yang diselenggarakan oleh Lintas Warna yang sudah rutin setiap tahunnya diselenggarakan.

Alasan peneliti meneliti kegiatan promosi All About Wedding yang dilaksanakan pada tanggal 19 Desember 2015 ini karena hasil pra riset peneliti mewawancarai owner Lintas Warna bernama Pak Iwan. Bahwa All About Wedding yang diselenggarakan pada tanggal 19 Desember 2015 ini adalah kegiatan promosi yang diselenggarakan secara besar-besaran oleh Lintas Warna dibandingkan kegiatan promosi sebelumnya. Bertujuan agar dapat meyakinkan peserta untuk menggunakan vendor wedding Lintas Warna. Pada All About 
Wedding ini Lintas Warna mengundang bintang tamu penyanyi Indonesia yaitu Terry sebagai penghibur sekaligus sebagai model dalam memeragakan busana pengantin karya vendor wedding busana pengantin management wedding Lintas Warna. Selain itu, pada kegiatan promosi ini terdapat demo dari setiap vendor wedding Lintas Warna.

Hal tersebut dilakukan dengan harapan dapat mencapai target Lintas Warna dimana $100 \%$ dari peserta kegiatan promosi All About Wedding akan menggunakan vendor wedding Lintas Warna di resepsi pernikahannya. Karena pada kegiatan-kegiatan sebelumnya $100 \%$ peserta kegiatan promosi oleh Lintas Warna event organizer yang hadir saat itu, menggunakan vendor wedding Lintas Warna dan melakukan pemesanan jasa Lintas Warna sebagai vendor wedding dalam resepsi pernikahannya.

Pada saat kegiatan ini berlangsung peserta All About Wedding mendapatkan informasi mengenai management wedding Lintas Warna tidak hanya dari kegiatan kegiatan promosi All About Wedding saja melainkan peserta menggabungkan informasi-informasi tersebut dengan brosur yang dibagikan Lintas Warna kepada peserta. Selain itu, peserta juga mendatangi penjaga pada stand Lintas Warna event organizer saat pameran berlangsung. Peserta menghampiri stand Lintas Warna ketika kegiatan promosi All About Wedding telah selesai dilaksanakan.

Berdasarkan latar belakang yang sudah dipaparkan, peneliti menemukan sebuah permasalahan mengenai pandangan peserta terhadap informasi yang mereka dapat dalam kegiatan promosi All About Wedding. Peneliti mewawancarai beberapa calon pengantin yang ditemui saat pameran dan mengikuti kegiatan promosi All About Wedding yang memberikan komentar mengenai informasi dalam kegiatan promosi All About Wedding.

Peserta All About Wedding yang pertama ditemui oleh penulis memandang bahwa informasi yang disampaikan pada saat kegiatan promosi tersebut adalah informasi yang tidak lengkap. Peserta ini membandingkan antara informasi pada brosur yang ternyata berbeda dengan informasi pada kegiatan promosi juga informasi dari penjaga stand Lintas Warna. Maka dari itu, informasi pada kegiatan promosi All About Wedding cenderung 
dipandang kurang meyakinkan peserta untuk menggunakan vendor wedding Lintas Warna. Peserta kegiatan promosi All About Wedding yang kedua yang ditemui penulis memandang bahwa informasi yang didapat dari kegiatan promosi All About Wedding ini terdapat informasi yang tidak tepat disampaikan. Berkaitan dengan informasi yang disampaikan melalui demo saat kegiatan promosi tidak sesuai dengan informasi yang dibutuhkan oleh peserta. Sehingga membuat peserta ini tidak jadi untuk menggunakan vendor wedding Lintas Warna sebagai vendor wedding dalam resepsi pernikahannya.

Pandangan- pandangan dari peserta tersebut dikhawatirkan karena adanya faktor informasi yang kurang tepat disampaikan. Berkaitan dengan panduan informasi yang digunakan oleh si pembicara dalam kegiatan promosi berbeda dengan panduan informasi yang digunakan oleh si penjaga stand Lintas Warna event organizer dalam pameran. Terutama mengenai paket-paket maupun promo yang tersedia dalam vendor wedding Lintas Warna.

Pada penelitian ini valensi informasi dan bobot informasi tidak mampu mendukung atau menyokong keyakinan dari peserta. Dimana peserta All About Wedding sebelum menghadiri kegiatan promosi sudah mendapatkan informasi mengenai management wedding Lintas Warna beserta vendor-vendor didalamnya dan mengenai kegiatan promosi yang diselenggarakan oleh Lintas Warna dari website Lintas Warna dan website bridestory.com. Hal tersebut membentuk anggapan dan keyakinan dari peserta bahwa Lintas Warna akan memberikan informasi baru yang dapat menyokong keyakinan mereka bahwa informasi dalam kegiatan promosi dapat meyakinkan dan mendorong mereka untuk menggunakan vendor wedding Lintas Warna.

Sejalan dengan hal tersebut, di dalam penelitian ini, teori integrasi informasi digunakan untuk melihat sejauhmana peserta kegiatan promosi All About Wedding yang diterpa berbagai informasi dalam kegiatan promosi mampu mengintegrasikan informasi tersebut. Untuk itu peneliti mengangkat judul penelitian "Hubungan Informasi Dalam 
Kegiatan Promosi All About Wedding dengan Sikap Peserta Terhadap Vendor Wedding Lintas Warna".

\section{TINJAUAN PUSTAKA}

Penelitian ini bertujuan meneliti hubungan informasi dalam kegiatan promosi All About Wedding dengan sikap peserta terhadap vendor wedding Lintas Warna. Pada penelitian ini meneliti mengenai informasi yang mendukung keyakinan, informasi yang jelas, relevan dan akurat pada kegiatan ini dengan sikap peserta terhadap vendor wedding Lintas Warna. Maka dari itu pada penelitian ini digunakan teori integrasi informasi (Integration Information Theoory).

Penelitian ini menggunakan teori Integrasi Informasi (Integration Information Theory) yang dikemukakan oleh Martin Fishbein dimana teori ini berhubungan dengan cara kita mengakumulasikan dan mengatur informasi tentang semua orang, objek, situasi dan gagasan yang membentuk sikap atau kecenderungan untuk bertindak dengan cara yang positif atau negative terhadap beberapa objek (Littlejohn,2014:111). Informasi merupakan sebuah kekuatan dalam system interaksi yang memiliki potensi dalam mempengaruhi sikap dan kepercayaan seseorang yang berdampak pada perubahan sikap seseorang.

Teori integrasi Informasi adalah salah satu model paling popular yang menawarkan untuk menjelaskan pembentukan informasi dan perubahan sikap. Semua informasi memiliki kekuatan potensial yang dapat mempengaruhi perubahan sikap.

1. Valensi, adalah arahan mengacu pada apakah informasi mendukung keyakinan atau menyangkal keyakinan (Littlejohn,2014:111). Seberapa besar informasi tersebut dapat mendukung kepercayaan yang telah dimiliki sebelumnya. Hal ini memberikan pengaruh pada kekuatan informasi untuk membentuk sikap. Jika informasi tersebut mendukung kepercayaan yang suudah ada, maka informasi tersebut dianggap sebagai informasi positif.

2. Bobot adalah sebuah kegunaan dari kredibilitas. Apabila informasi dianggap benar maka bobot yang diberikan akan lebih tinggi, juga sebaliknya (Littlejohn,2014:111). 
Seberapa besar informasi itu dapat dipercayai kebenarannya (berkaitan dengan kredibilitas informasi dan sumber informasi). Hal ini memberikan pengaruh pada seberapa besar pengaruh yang muncul. Apabila kredibilitas informasi rendah, maka pengaruh yang timbul lebih kecil walaupun informasi tersebut mendukung kepercayaan yang sudah ada.

Akumulasi dari informasi tentang objek, orang atau situasi dapat mempengaruhi konsep sikap seseorang. Apabila seseorang menilai positif informasi yang diterimanya, maka ia akan mengubah sikapnya terhadap suatu objek sesuai dengan konsep baru yang diterimanya melalui informasi yang disampaikan. Demikian pula sebaliknya yang terjadi apabila informasi dinilai negative maka seseorang cenderung tidak akan mengubah struktur sikapnya terhadap suatu objek.

Perubahan sikap dapat terjadi karena adanya informasi dari yang ditambahkan pada sikap. Perubahan sikap juga dapat terjadi karena perubahan penilaian orang yang bersangkutan terhadap informasi yang diperoleh sebelumnya. Sikap berkorelasi dengan kepercayaan dan kemungkinan perilaku seseorang terhadap objek yang dihadapi.

Teori integrasi informasi terdiri dari tiga komponen yaitu informasi, individu atau orang dan sikap. Informasi merupakan stimulus yang diberikan, semua jenis informasi memiliki potensi untuk mempengaruhi komponen yang kedua, yakni individu. Individu merupakan orang yang memberikan stimuli berupa informasi dalam bentuk apapun, informasi yang diberikan oleh individu dapat merubah atau meneguhkan komponen yang ketiga yakni sikap dari penerima informasi. Dimana sikap dianggap sebagai sebuah akumulasi dari informasi tentang sebuah objek, seseorang, situasi atau pengalaman. (Littlejohn, 2014:111).

Sejalan dengan hal tersebut, di dalam penelitian ini, teori integrasi informasi digunakan untuk melihat sejauhmana peserta kegiatan promosi All About Wedding yang diterpa berbagai informasi dalam kegiatan promosi mampu mengintegrasikan informasi 
tersebut. Komponen infromasi dalam penelitian ini adalah kegiatan promosi "All About Wedding" dimana didalamnya terdapat informasi-informasi seputar vendor wedding Lintas Warna beserta inovasi-inovasi terbaru dari setiap vendor, informasi mengenai kualitas jasa dan produk dari setiap vendor wedding Lintas Warna dan penawaran promo, diskon dan bonus dari Lintas Warna.

\section{METODE PENELITIAN}

Metode korelasi bertujuan meneliti sejauh mana variasi pada suatu factor berkaitan dengan variasi pada faktor lain. Tetapi dalam metode ini tidak dimaksudkan untuk menguji hipotesis atau melakukan sebuah prediksi. Dimana dalam bahasan metode korelasional menurut Isaac dan Michael dalam Metode Penelitian Komunikasi (Rakhmat,2012:27):

"Metode korelasional sebenarnya kelanjutan dari metode deskriptif. Dengan metode deskriptif,kita menghimpun data, menyusunnya secara sistematis, factual dan cermat".

Pada penelitian ini metode penelitian yang digunakan adalah metode korelasinal. Metode korelasional ini digunakan dalam penelitian karena dianggap sesuai dengan tujuan yang ingin dicapai peneliti yaitu memperoleh kejelasan hubungan secara sistematis, faktual dan akurat mengenai hubungan antara informasi pada kegiatan promosi All About Wedding dengan Sikap Peserta terhadap Vendor Wedding Lintas Warna yang diinformasikan dalam kegiatan ini.

Populasi pada penelitian ini adalah seluruh peserta Kegiatan Promosi All About Wedding pada anggal 19 Desember 2015 bejumlah 284 orang. Untuk teknik sampling yang digunakan dalam penelitian ini adalah sampel acak sederhana. Berdasarkan hasil perhitungan, maka ukuran sampel yang representatif untuk penelitian ini adalah sekurangkurangnya 72 sampel. 


\section{HASIL DAN PEMBAHASAN}

Berdasarkan pemaparan yang sudah dijelaskan sebelumnya dalam penelitian ini, Informasi dalam Kegiatan Promosi All About Wedding (X) diturunkan menjadi dua sub variabel, yaitu valensi informasi (X1) dan bobot informasi (X2), sedangkan sikap peserta terhadap vendor wedding Lintas Warna (Y) memiliki tiga dimensi, yaitu kognitif, afektif, dan konatif.

Hasil penelitian ini merupakan data yang dihimpun melalui kuesioner yang disebarkan kepada 72 orang. Hasil dari angket yang telah disebarkan terdiri dari data responden dan data penelitian sejumlah 5 pertanyaan data responden dan 23 pertanyaan data penelitian.

\section{Rekapitulasi Hasil Analisis Inferensial}

\begin{tabular}{|c|c|c|c|c|c|c|}
\hline Variabel & $r_{s}$ & $\mathrm{t}$ hitung & $t_{\text {(tabel) }}$ & Keterangan & Kriteria & Kesimpulan \\
\hline $\begin{array}{l}\text { Informasi (X) } \\
\text { \& Sikap } \\
\text { Peserta (Y) }\end{array}$ & 0.660 & 7.350 & & Ho ditolak & $\begin{array}{c}\text { Hubungan } \\
\text { yang cukup } \\
\text { berarti }\end{array}$ & \\
\hline & 0.700 & 8.201 & 1.994 & Ho ditolak & $\begin{array}{c}\text { Hubungan } \\
\text { yang cukup } \\
\text { berarti }\end{array}$ & $\begin{array}{l}\text { Terdapat } \\
\text { Hubungan }\end{array}$ \\
\hline $\begin{array}{c}\text { Bobot } \\
\text { Informasi } \\
\text { (X2) \& Sikap } \\
\text { Peserta (Y) }\end{array}$ & 0.527 & 5.188 & 1.994 & Ho ditolak & $\begin{array}{c}\text { Hubungan } \\
\text { yang cukup } \\
\text { berarti }\end{array}$ & \\
\hline
\end{tabular}


Sumber : Pengolahan Data Tahun 2016

Berdasarkan hasil uji siginifikansi menunjukkan bahwa valensi dan bobot informasi dalam kegiatan promosi All About Wedding sudah dapat membentuk perubahan sikap peserta. Informasi adalah salah satu dari kekuatan system interaksi dan berpotensi untuk memengaruhi sebuah system kepercayaan atau sikap individu." (Littlejohn,2014:111).

Informasi sangat berkaitan dengan seluruh aktivitas manusia. Aktivitas manusia tidak akan lepas dari kebutuhan informasi. Informasi sangat diperlukan dalam kehidupan sehari-hari maupun kelompok atau organisasi. Informasi adalah salah satu kekuatan dari system interaksi yang dapat mempengaruhi sikap individu dan perubahan sikap dari individu. Pengaruhnya akan timbul secara langsung atau secara tidak langsung. Gordon. B. Davis dalam buku Analisis dan Desain Sistem Informasi (Al-Bahra,2005:8) mendefinisikan informasi sebagai berikut "Informasi sebagai data yang telah dioleh menjadi bentuk yang lebih berarti dan berguna bagi penerimanya untuk mengambil keputusan masa kini maupun yang akan datang".

Mengacu pada tabel di atas, dapat diketahui bahwa perubahan sikap dapat pula dipengaruhi oleh dua variable yaitu valensi dan bobot. Selanjutnya, ditemukan hasil bahwa antara variable Informasi Dalam Kegiatan Promosi All About Wedding dengan sikap peserta terhadap vendor wedding Lintas Warna terdapat hubungan yang cukup berarti. Sesuai dengan angka yang terdapat pada koefisien korelasi Rank Spearman (rs) pada table analisis inferensial Informasi $(X)$ \& Sikap Peserta $(Y)$ berjumlah 0.660. Lalu, disesuaikan dengan table Guilford yang menyatakan bahwa koefisien korelasi yang berjumlah 0.660 itu termasuk pada kriteria hubungan yang cukup berarti. Informasi dalam kegiatan promosi All About Wedding memiliki hubungan yang cukup berarti namun belum cukup dapat membentuk perubahan sikap dari peserta kegiatan promosi All About Wedding untuk menggunakan vendor wedding Lintas Warna.

Dalam hal ini sesuai dengan salah satu fungsi informasi yaitu menambah pengetahuan. Dimana adanya informasi akan menambah pengetahuan bagi penerimanya 
yang dapat digunakan sebagai bahan pertimbangan yang mendukung proses pengambilan keputusan (Sutanta,2003:11). Sikap dari peserta ini dikarenakan adanya pandangan bahwa peserta kurang memahami akan informasi yang mereka dapat dari kegiatan promosi All About Wedding.

Dikarenakan informasi yang dianggap kurang jelas, tidak detail dan kurang meyakinkan peserta ketika peserta mengakumulasikan informasi yang didapat dari kegiatan promosi juga dari brosur dan penjaga stand Lintas Warna. Sehingga pada hal ini informasi pada kegiatan promosi All About Wedding sudah mampu membentuk perubahan sikap dari peserta walaupun belum sepenuhnya membentuk sikap sesuai apa yang diinginkan oleh perusahaan.

Pada prinsipnya promosi adalah upaya untuk mempengaruhi target sasaran, seperti yang dikemukakan berikut: "Promotion is marketers effort to communicate with target audiences. Communication is the process of influencing others behavior by sharing ideas, information or feeling with them". (Alma,2011:179).

Berdasarkan hasil penelitian dan penghitungan statistik terhadap data yang telah dikumpulkan penulis melalui angket, diketahui bahwa hubungan yang paling tinggi adalah hubungan antara Valensi Informasi dalam kegiatan promosi All About Wedding (X) dengan Sikap Peserta $(Y)$ terhadap vendor wedding Lintas Warna dengan koefisien korelasi sebesar $(0,700)$. Menurut Guilford koefisien korelasi sebesar 0.700 termasuk pada kriteria hubungan yang cukup berarti.

Hubungan yang cukup berarti ini dapat terjadi karena informasi yang disajikan dalam kegiatan promosi All About Wedding dilengkapi fakta salah satunya terdapat sesi demo sebagai media penyampaian informasi secara visual. Lalu, terdapat pemutaran video-video testimony dari klien yang sudah menggunakan jasa vendor wedding Lintas Warna. Sehingga informasi yang disampaikan pada kegiatan promosi All About Wedding ini sudah dapat mendukung keyakinan peserta dari keyakinan yang sudah dimiliki peserta sebelumnya. Peserta hadir pada kegiatan promosi All About Wedding pada ummnya berdasarkan 
keyakinan yang sebelumnya telah ia miliki karena sebelumnya peserta telah mendapatkan informasi mengenai management wedding Lintas warna dari sumber informasi lain maupun dari kerabat atau keluarga yang sudah menggunakan jasa management wedding Lintas Warna.

Dengan kata lain, peserta telah mengevaluasi terlebih dahulu informasi yang didapat sebelumnya sehingga menghasilkan keyakinan. Keyakinan ini menyangkut pada informasi mengenai Lintas Warna event organizer dan management wedding Lintas Warna yang sudah didapat peserta sebelumnya lalu diakumulasikan dengan informasi yang didapat dari sumber-sumber informasi pada kegiatan promosi seperti pembicara pada kegiatan promosi, brosur dan penjaga stand.

Namun pada peneliltian ini masih terdapat peserta yang menyatakan bahwa informasi pada kegiatan promosi All About Wedding masih terdapat kekurangan dimana informasinya simpang siur dan terkesan tidak selaras antara informasi yang disampaikan oleh pembicara pada kegiatan promosi dan informasi yang disampaikan oleh penjaga stand juga pada brosur. Berkaitan dengan informasi mengenai paket pernikahan dari management wedding Lintas Warna.

Sehingga masih terdapat peserta yang merasa kurang yakin akan informasi yang didapat dari kegiatan promosi juga dari brosur dan penjaga stand Lintas Warna. Namun secara garis besar informasi yang disampaikan pada kegiatan promosi All About Wedding sudah dapat membentuk perubahan sikap yang positif dari peserta terhadap vendor wedding Lintas Warna dillihat dari hubungan valensi informasi pada sikap yang cukup berarti sehingga menunjukkan bahwa secara garis besar informasi dipandang mendukung keyakinan peserta dengan keyakinan yang sudah dimiliki sebelumnya.

Sedangkan untuk hubungan yang paling rendah, yaitu hubungan antara Bobot Informasi (X2) dan Sikap (Y) peserta terhadap vendor wedding Lintas Warna dengan koefisien korelasi sebesar (0.527). Hubungan yang cukup berarti ini dikarenakan bobot informasi pada kegiatan promosi All about wedding yang menitik beratkan pada kualitas 
informasi yang berfungsi untuk membuat para peserta menganggap informasi yang ada pada kegiatan promosi ini adalah suatu kebenaran.Informasi sudah dikemas sesuai dengan faktor-faktor yang membentuk kualitas atau kredibilitas informasi, yaitu kejelasan, relevansi (kecocokan) dan keakuratan (ketelitian) informasi.

Namun pengemasan informasi untuk membentuk kejelasan dan relevansi informasi masih kurang sehingga masih terdapat peserta yang menilai bahwa informasi pada kegiatan promosi ini kurang jelas, kurang detail disampaikan. Berkaitan dengan penyampaian informasi mengenai paket pernikahan dan bonus yang dipromosikan pada kegiatan promosi All About Wedding. Sehingga informasi tidak memiliki kejelasan dan relevansi yang maksimal.

Selain itu, topik yang disampaikan masih tidak terlalu fokus, terutama pada sesi demo dari vendor wedding Lintas Warna masih terdapat penilaian dari peserta bahwa sesi demo tersebut menyampaikan informasi yang tidak focus menyampaikan mengenai kualitas secara nyata dari setiap vendor wedding Lintas Warna, sehingga terkesan seperti sedang mengadakan sebuah pertunjukan atau konser. Pada buku Komunikasi Bisnis dan Profesional dalam Curtis (2006:267) membahas mengenai relevansi sebagai salah satu hal yang harus dicapai agar informasi berdampak positif pada sikap penerima informasi.

"Relevansi adalah tujuan lain dalam persiapan penyampaian informasi(persentasi). Apabila anda menyampaikan informasi, anda harus membuat informasi itu relevan dengan para penyimak anda."

Hal tersebut membuat topik yang disajikan kurang sesuai dengan peserta yang hadir pada kegiatan promosi yang mayoritas ingin mengetahui informasi secara jelas dan detail mengenai management wedding Lintas Warna serta ingin melihat kualitas melalui demo dari setiap vendor secara langsung. Hal ini juga membuat peserta masih kebingungan dan ragu untuk menggunakan vendor wedding Lintas Warna.

Keraguan merupakan salah satu bentuk konasi. Dimensi perilaku atau Dimensi konatif dalam struktur sikap menunjukkan bagaimana perilaku atau kecenderungan 
berperilaku yang ada dalam diri seseorang berkaitan dengan objek sikap yang dihadâpinya (Azwar,2013:27). Oleh karena itu, dapat dikatakan bahwa bobot informasi pada kegiatan promosi All About Wedding kurang dapat membentuk sikap peserta juga keyakinan peserta.Maka dari itu, bobot informasi yang diberikan oleh peserta pada informasi dalam kegiatan promosi ini cenderung rendah.

\section{SIMPULAN DAN SARAN}

1. Valensi informasi memiliki hubungan yang cukup berarti dengan sikap peserta terhadap vendor wedding Lintas Warna.

Hubungan yang cukup berarti ini terjadi karena informasi sudah cukup dapat meyakinkan sebagian besar dari peserta. Namun masih terdapat peserta yang menilai informasi pada kegiatan promosi All About Wedding simpang siur dan terkesan tidak selaras antara informasi yang disampaikan oleh pembicara pada kegiatan promosi dan informasi yang disampaikan oleh penjaga stand juga pada brosur. Berkaitan dengan informasi tentang paket pernikahan management wedding Lintas Warna. Sehingga masih terdapat peserta yang merasa kurang yakin akan informasi yang didapat dari kegiatan promosi juga dari brosur dan penjaga stand Lintas Warna.

2. Bobot informasi memiliki hubungan yang cukup berarti dengan sikap peserta terhadap vendor wedding Lintas Warna. Hubungan yang cukup berarti ini dapat disebabkan karena informasi pada kegiatan promosi All About Wedding sudah cukup dapat membuat sebagian besar peserta menganggap benar pada informasi tersebut. Namun masih terdapat informasi yang disajikan dalam kegiatan promosi All About Wedding yang dinilai kurang jelas, simpang siur, topik yang disampaikan masih tidak focus. Berkaitan dengan sesi demo dari vendor wedding Lintas Warna masih terdapat penilaian dari peserta bahwa sesi demo tersebut tidak focus menyampaikan mengenai kualitas secara nyata dari setiap vendor wedding Lintas Warna. Hal ini membuat para peserta kesulitan untuk memahami isi informasi dan menjadi kurang yakin untuk menggunakan vendor wedding 
Lintas Warna Informasi inilah yang menjadi dasar bagi terbentuknya sikap peserta terhadap vendor wedding Lintas Warna.

\section{SARAN}

1. Sebaiknya, Lintas Warna event organizer melakukan pemeriksaan ulang terhadap panduan informasi pada kegiatan promosi All About Wedding agar informasi yang disampaikan oleh pembicara pada kegiatan promosi All About Wedding sama dengan informasi yang disampaikan oleh penjaga stand Lintas Warna juga informasi pada brosur. Sehingga informasi pada kegiatan promosi dapat dipandang sebagai inormasi yang menndukung keyakinan peserta.

2. Sebaiknya, Informasi tentang vendor wedding Lintas Warna dari mulai kualitas jasa dan produk, harga, bonus dan diskon yang ditawarkan sebaiknya dijelaskan secara lebih detail, rinci dan jelas. Agar peserta memahami dan merasa puas akan informasi yang mereka akumulasikan dengan informasi pada brosur dan penjaga stand. Dikarenakan masih terdapat peserta yang menyatakan bahwa informasi pada kegiatan promosi $A / l$ About Wedding kurang meyakinkan karena informasi tidak detail, rinci dan jelas.

\section{DAFTAR PUSTAKA}

Al-Bahra bin Ladjamudin.2005.Analisis Dan Desain Sistem Informasi.Yogyakarta :Graha IImu Alma, Buchari.2011.Manajemen Pemasaran Dan Pemasaran Jasa.Bandung:Alfabeta Azwar, Saifuddin.2013. Sikap Manusia, Teori dan Pengukurannya. Yogyakarta: Pustaka Pelajar.

Curtis, Floyd dan Jerry L.Winsor.2006. Komunikasi Bisnis dan Profesional. Bandung: PT. Remaja Rosdakarya.

Littlejohn, Stephen W.2014. Teori Komunikasi. Jakarta: Salemba Humanika.

Rakhmat, Jalaluddin.2012. Metode Penelitian Komunikasi. Bandung: PT.Remaja Rosdakarya .2012.Psikologi Komunikasi. Bandung:PT.Remaja Rosdakarya

Sutanta, Edhy.2003. Sistem Informasi Manajemen. Yogyakarta:Graha Ilmu 
JURNAL LISKI | Vol. 2. No. 2 | 2016

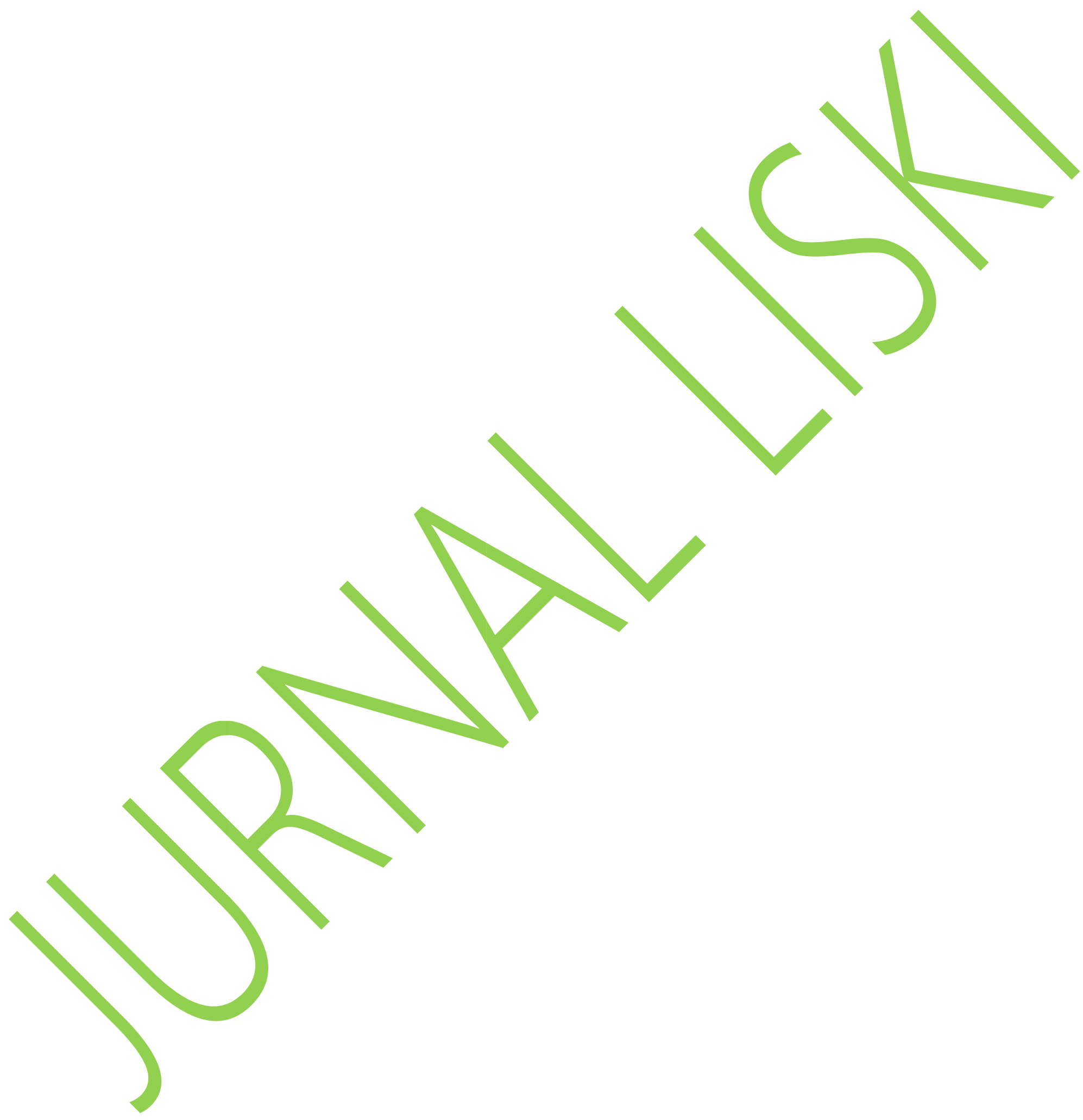

